\title{
Potable Water Hygiene from the Stagnation of Water Point of View
}

\author{
Jana Peráčková1*, Dominika Juhošová1 \\ ${ }^{1}$ Department of Building Services, Faculty of Civil Engineering, Slovak University of Technology in Bratislava, 81005 Bratislava, \\ 11 Radlinského, Slovakia \\ *Corresponding author, e-mail: jana.perackova@stuba.sk
}

Received: 23 May 2020, Accepted: 25 June 2020, Published online: 05 October 2020

\begin{abstract}
Potable and hygienically suitable water supply is important for both residential and commercial buildings. The contribution focuses on potable water hygiene and quality from the water stagnation point of view. Stagnation of water is very dangerous phenomena because it causes the change in water quality. Proper routing and arrangement of cold and hot water pipes can significantly reduce the risk of water stagnation. In the paper, the classical trunk-and-branch installation system with the hygienically more suitable alternatives are compared. The paper also provides the definition of potable water, basic factors affecting its quality and basic rules for its control. Keywords
\end{abstract}

potable water, water stagnation, sanitary installation, branch pipe

\section{Introduction}

The human body needs to receive a sufficient amount of potable water every day. It is very important to ensure the proper intake of potable water and it is even more important that the water we consume does not contain harmful contaminants and pathogens. Potable and hygienically suitable water supply is important for both residential and commercial buildings such as hospitals, schools, office buildings, hotels, retirement homes and others. Persons producing and supplying water intended for human consumption are obliged to ensure that the supplied potable water meets health safety requirements and that the limits of potable water quality indicators are checked and observed. In a building, a building operator is responsible for the water quality.

We could define potable water as a "water intended for human consumption" [1]:

1. all water either in its original state or after treatment, intended for drinking, cooking, food preparation or other domestic purposes, regardless of its origin and whether it is supplied from a distribution network, from a tanker, or in bottles or containers;

2. all water used in any food-production undertaking for the manufacture, processing, preservation or marketing of products or substances intended for human consumption unless the competent national authorities are satisfied that the quality of the water cannot affect the wholesomeness of the foodstuff in its finished form [1].
Potable water has to meet the requirements that are in accordance with a valid legislation. The potable water quality requirements which are valid in all Member States of the European Union are laid down in Council Directive 98/83/EC on the quality of water intended for human consumption. In the Council Directive, there are set limit values of various chemical parameters which have to be controlled in the potable water. The range and frequency of water quality control depends on the amount of supplying water and number of people living in a supplied area. The water quality control and its health safeness are determined through the water quality indicators representing the physical, chemical, biological and microbiological water properties [1].

\section{Basic factors affecting the potable water quality}

The most important factors affecting the potable water quality in buildings are:

- pipe material: the use of unsuitable materials and their unsuitable combination leads to an increased concentration of substances dissolved from the installed materials [2],

- water stagnation: the occurrence of too low water flow rate (oversized pipe diameter) or a disruption of water supply for a certain period of time cause a change in water quality and a greater risk of a bacteria Legionella spreading $[3,4]$, 
- technical solutions of the potable water distribution system in the building.

From the technical point of view, it is necessary to propose the proper water supply system solution-correctly designed pipe material in terms of water contamination by microorganisms, correct dimensioning, routing and water pipes isolating with regard to water temperature, water flow rate and water stagnation in the pipeline [5].

From the potable water hygiene point of view, continuous building operation and regular water abstraction from all water taps would be ideal. Under these conditions, the water always moves and there is no danger of stagnation. These ideal conditions are usually not found in the building, but the resulting hygienic risks can be reduced using the correct technical solution-manual or automatic flushing systems. There are also methods of connecting the water supply branch pipe to the water taps so that the entire section of the branch pipe is flushed each time the water tap is used [2].

\section{Branch pipes of water}

The branch pipe is a connecting pipe from the connection to a riser pipe and it conveys water to the release valves (Fig. 1).
Branch pipes should be placed:

1. in pre-wall system,

2. in slots or openings in a wall (there is a risk of noise),

3 . built in floor layers, installed in a protective sleeve.

If the potable water in branch pipe has stagnated for too long, it is prone to reach critical temperature ranges. Cold water temperature can rise above $15^{\circ} \mathrm{C}$ and hot water temperature can drop below $45^{\circ} \mathrm{C}$ thus creating the ideal conditions for microorganism growth.

The endangered are the rarely used release valves such as guest toilet, fire water system or water connection to a garden hose. If both bathtub and shower are available in the bathroom at the same time, the regular use of both water taps is generally not guaranteed. Reasonably designed piping can significantly reduce the stagnation risk, especially in rarely used taps, thereby contributing to maintaining potable water quality [2].

The contribution focuses on potable water hygiene from cold and hot water pipes routing point of view and its arrangement, using several alternatives of branch pipe installation described in the Subsections 4.1 to 4.5 [6].

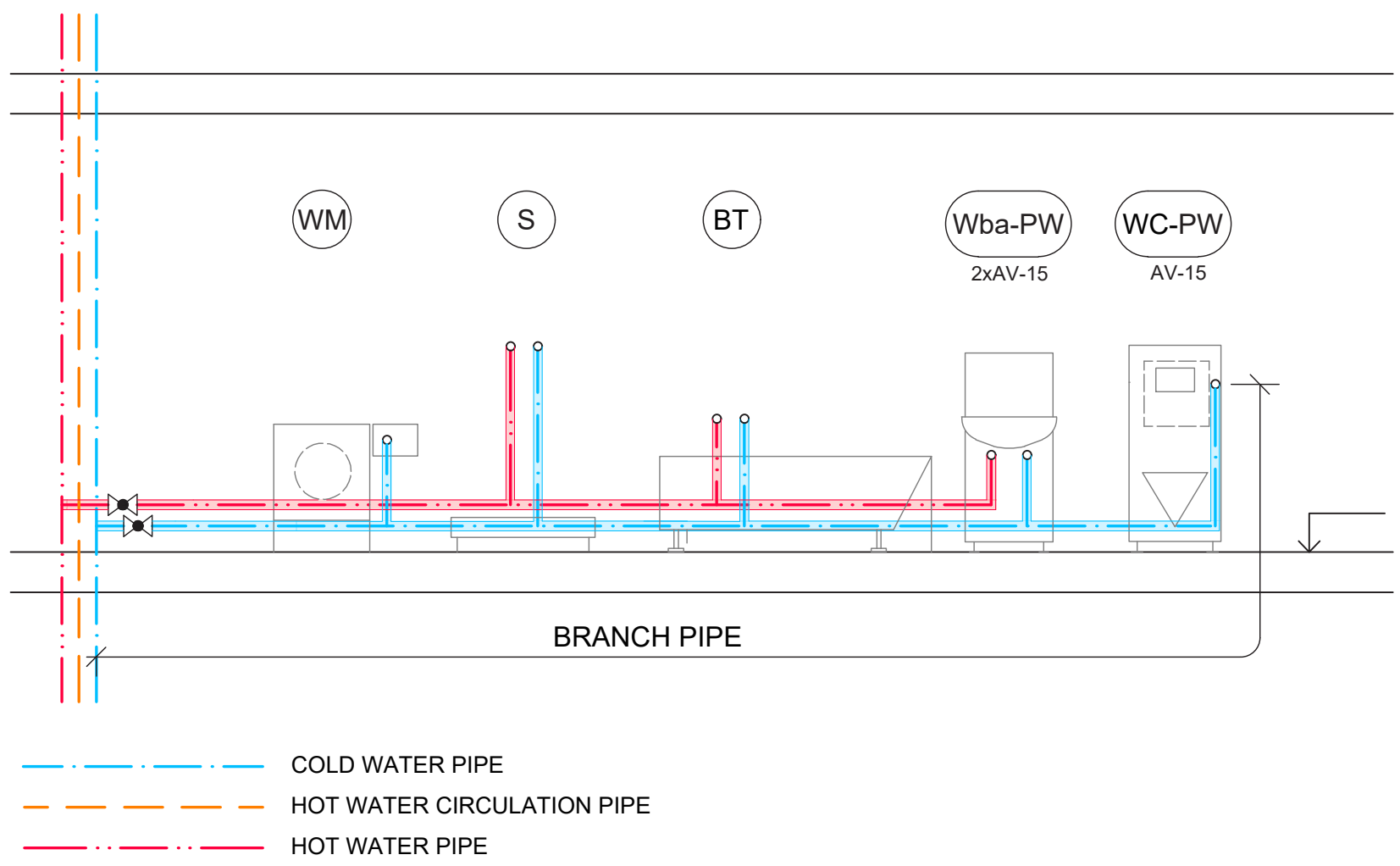

WM: Wash machine, S: Shower, BT: Bath, Wba-PW: Wash basin with a pre-wall system, WC-PW: Water closet with a pre-wall system, AV: angle valve

Fig. 1 Branch pipe of cold and hot water [author] 


\section{Alternative solutions of installation of branch pipes}

4.1 Trunk and branch system with a $T$-pieces fittings used for the connection of valves

Trunk and branch system consist of a branch pipe for hot and cold water and release valves (water taps) are connected to the branch pipe by T-pieces fittings (Fig. 2). The T-pieces system is the most popular way to configure tubing for domestic water. Provided that all release valves are used regularly, suitable conditions are created for the hygienic operation of the potable water pipeline. Rarely used pipeline sections can create suitable conditions for bacteria that contaminate the rest of the pipeline network. Using the T-piece fitting is not enough to flush the entire installed system [6]:

1. Advantages of the Trunk and branch system:

- less material consumption

- is the cheapest solution

- branch pipes can be routed in the slots

- favorable hydraulics

- when all appliances are used regularly, the proper potable water hygiene is ensured

2. Disadvantages of the Trunk and branch system:

- a) large number of fittings make the installation slower and more likely to leak

- b) risk of stagnation in irregularly used pipe sections

3. Recommendation:

- A regularly used sanitary appliance, e.g. WC or wash basin, should be placed at the end of the branch pipe [6].

\subsection{Branch pipes with a separated pipe for each tap connected to a manifold}

The second installation type consists of a separate cold and hot water branch pipe for each water tap (Fig. 3). It requires the installation of a manifold for cold and hot water and each supply point is connected individually by a separate branch pipe. Assuming that all water taps are used regularly, good conditions for the hygienic operation of the system are created.

The solution presents a higher potable water hygiene standard with respect to the short pipeline flushing time, but using only one release valve is not sufficient to flush the entire installation. In the case of an operation interruption, all release valves must be flushed. A rarely used pipe sections are dangerous from the water stagnation point of view:

1. Advantages of a manifold installation:

- balanced hydraulics

- lower pressure losses

- smaller piping dimensions

- low water volume in the pipeline

- when all appliances are used regularly, the proper potable water hygiene is ensured

2. Disadvantages of a manifold installation:

- a) greater material consumption

- b) more expensive solution

- c) risk of stagnation in irregularly used pipe sections

The arrangement of the sanitary appliances does not affect the potable water hygiene; therefore the sanitary appliances can be arranged randomly [6].

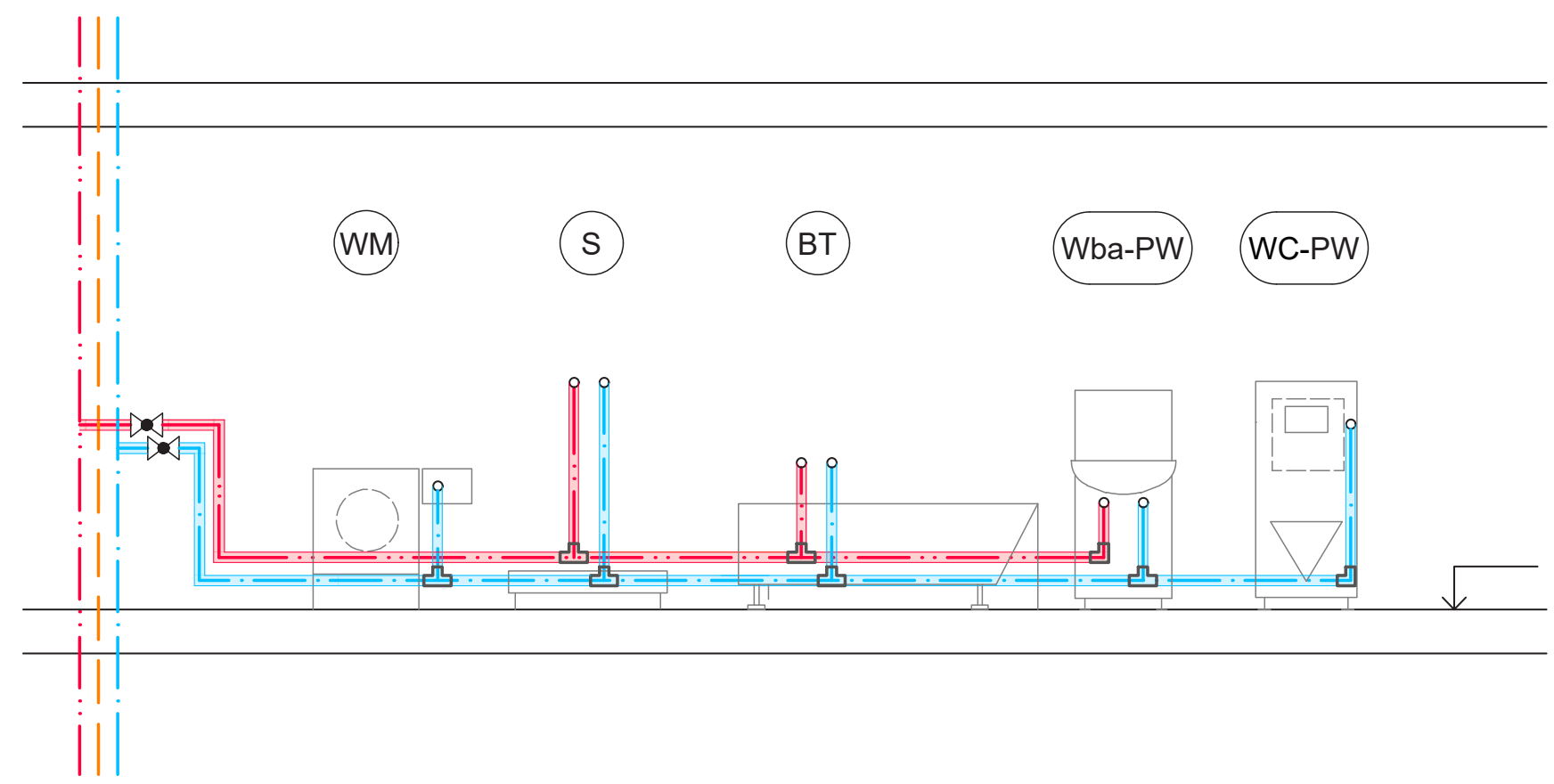

Fig. 2 Trunk and branch system with a connection of valves using T-pieces fittings [author] 


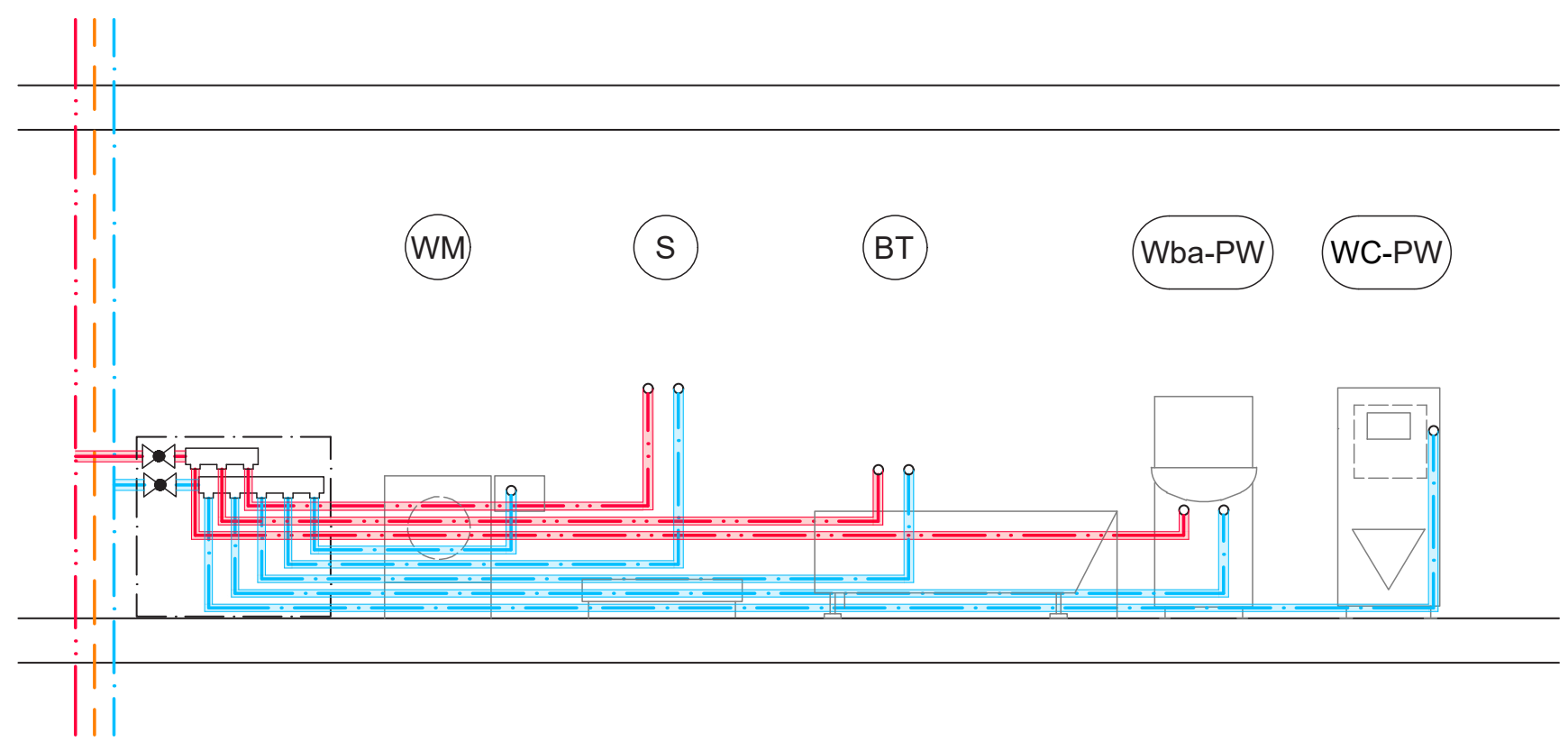

Fig. 3 Branch pipes connected to a manifold with a separated pipe for each tap [author]

\subsection{Continuous branch pipe connected to the water tap via special flow-through valve}

The third alternative consists of a continuous branch pipe installation (Fig. 4) with connection to the release valve via special flow-through valve (Fig. 5).

When tapping water from the water tap, the water passes through all valves sequentially, which significantly reduces the risk of water stagnation due to better water flushing in the pipeline installation [7]. This installation type is not yet widespread, but it becomes increasingly important. This type of installation presents a hygienic improvement over the established variants described in the Subsections 4.1 and 4.2 [6]:

1. Advantages of a continuous branch pipe installation:

- less material consumption

- better flushing

- the risk of water stagnation is significantly reduced

2. Disadvantages of a continuous branch pipe installation:

- a) increased pressure losses

- b) larger pipe dimensions

- c) more expensive solution due to the use of special flow-through valves (Fig. 5)

3. Recommendation:

- The last sanitary appliance within the pipeline section should be the most commonly used one, e.g. WC or a wash basin, since the complete water change is ensured by opening the last water tap.

\subsection{Continuous branch pipe connected to the release valve with a ring mains}

In this installation type, each release valve is connected to water supply from two sides via special flow-through valves (Fig. 5) while the branch pipe is circled (Fig. 6).

As the water flows from two sides to each valve, the entire volume of water in the pipeline is actuated at each tap. Opening any mixer tap will change the water along the entire route, minimizing the risk of water stagnation. The water stagnation risk is minimal and the negative impact on the potable water quality is thus reduced as much as possible:

1. Advantages of a ring mains installation:

- pressure losses are minimized

- balanced hydraulics

- smaller piping dimensions

- low water volume in the pipeline

- better pipeline system flushing

- the water stagnation risk is reduced to the minimum

2. Disadvantages of a ring mains installation:

- higher material consumption

- more expensive solution due to the use of special flow-through valves

The arrangement of the sanitary appliances does not affect the potable water hygiene, therefore the sanitary appliances can be arranged randomly [6]. 


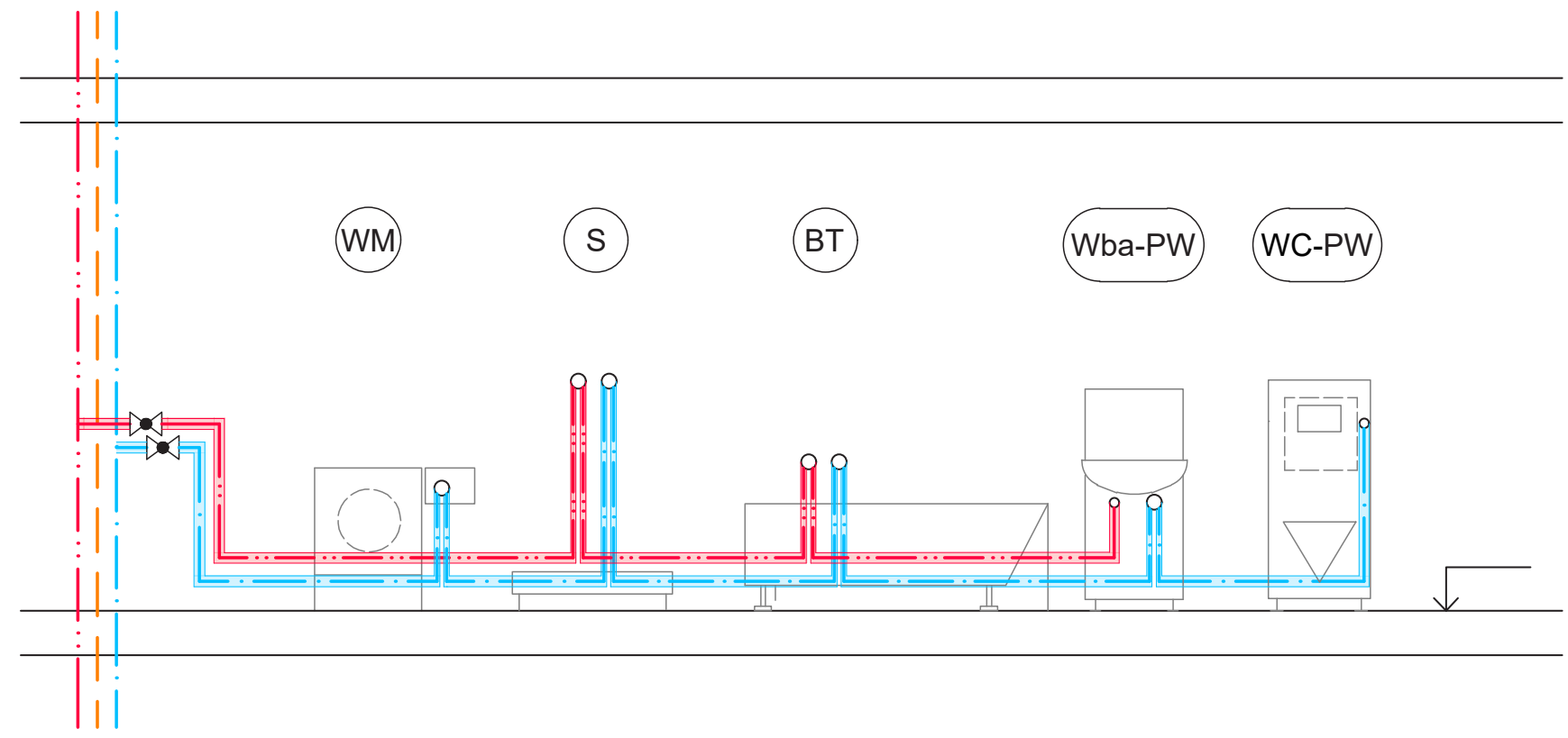

Fig. 4 Continuous branch pipe connected to the release valve via special flow-through valve [author]
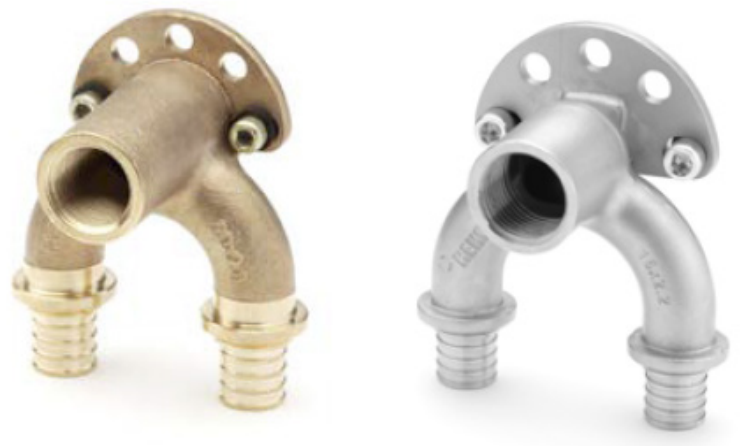

Fig. 5 Flow-through valves, brass and stainless-steel alternative [8]

\subsection{Branch pipe connection with a ring mains with a hot water circulation}

The last installation type is a circuit continuous connection with a hot water circulation (Fig. 7). The hot water circulation is necessary to design in the case of very long pipes for hot water in order to ensure the proper temperature of hot water in a short time period. This installation type presents a very high standard of potable water hygiene solution. Its disadvantage is that using a circulation of hot water, the measure of hot water consumption is impossible, which can be a complication in billing the hot water consumption in some type of objects. Another disadvantage is the need of installation of regulating valve in the hot water circulation pipe:

1. Advantages of a ring mains installation with a hot water circulation:

- balanced hydraulics

- low water volume in the pipeline

- better pipeline system flushing
- the risk of a water stagnation and bacteria Legionella spreading is reduced

2. Disadvantages of a ring mains installation with a hot water circulation:

- higher material consumption

- more expensive solution

- complications in measuring the hot water consumption

- need of regulating valves in the circulation pipe

For sanitary appliances that are less used in the building and where is a risk of water stagnation a continuous branch pipe with a ring mains in combination with a Venturi flow splitter is recommended.

These flow splitters allow the flow to be split into the main (rising) pipe and branching (ring) pipe without additional control valves. The operation is based on the Venturi effect principle (Fig. 8). Due to the narrowing of the pipeline's internal diameter, the pressure difference is created and it forces the water flow to be split into the rising pipe and branch pipe.

Approximately 5-10\% of the total water flowing volume passes through the branch pipe. This water proportion passes through the branch pipe and flushes it without opening the release valve which minimizes the risk of stagnation of water in the pipe section [9].

The use of flow splitters is very favorable for that sanitary appliances, which are used irregularly, e.g. water connection to a garden hose (Fig. 9), to a guest bathroom, filling the heating system with the potable water etc. 


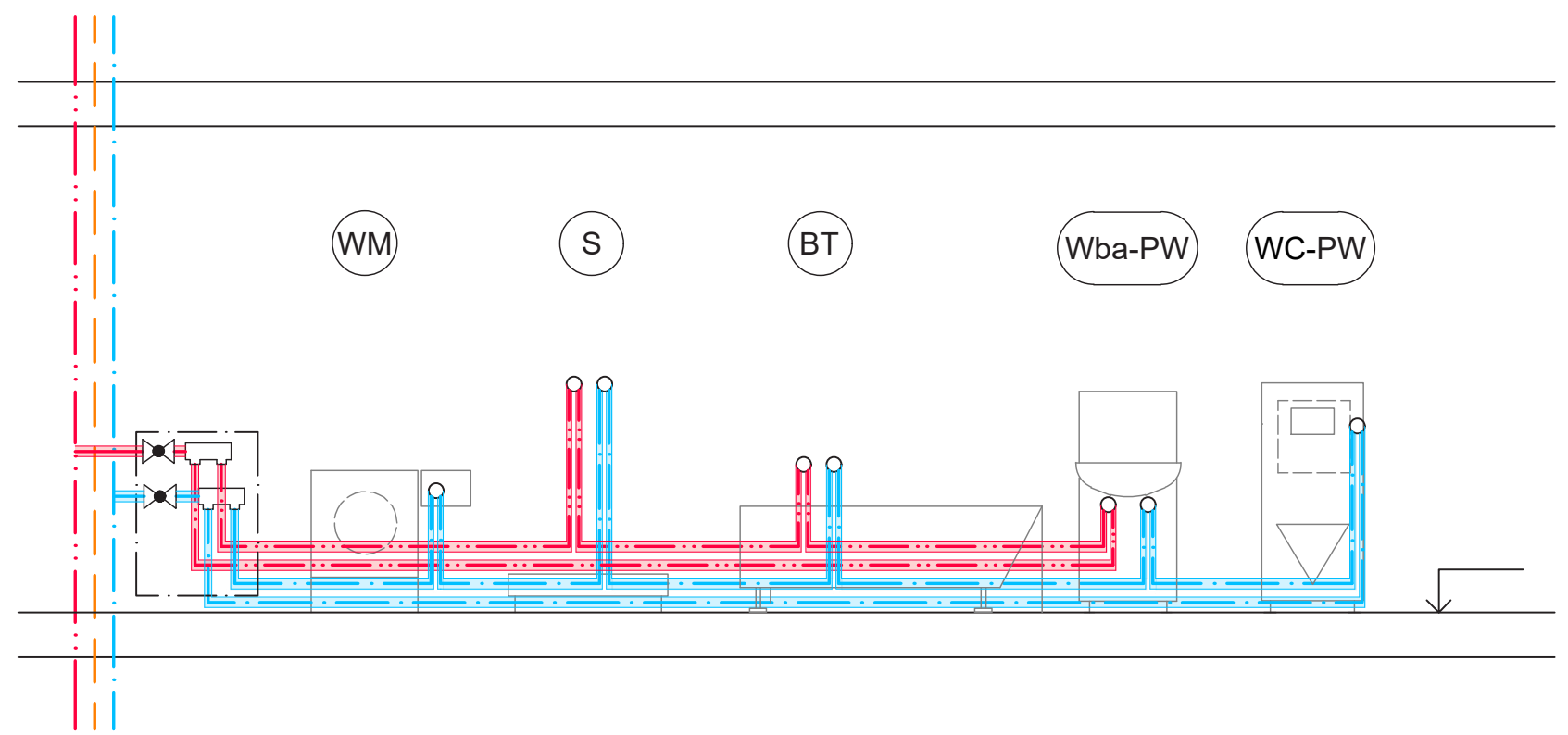

Fig. 6 Continuous branch pipe connected to the release valve with a ring mains [author]

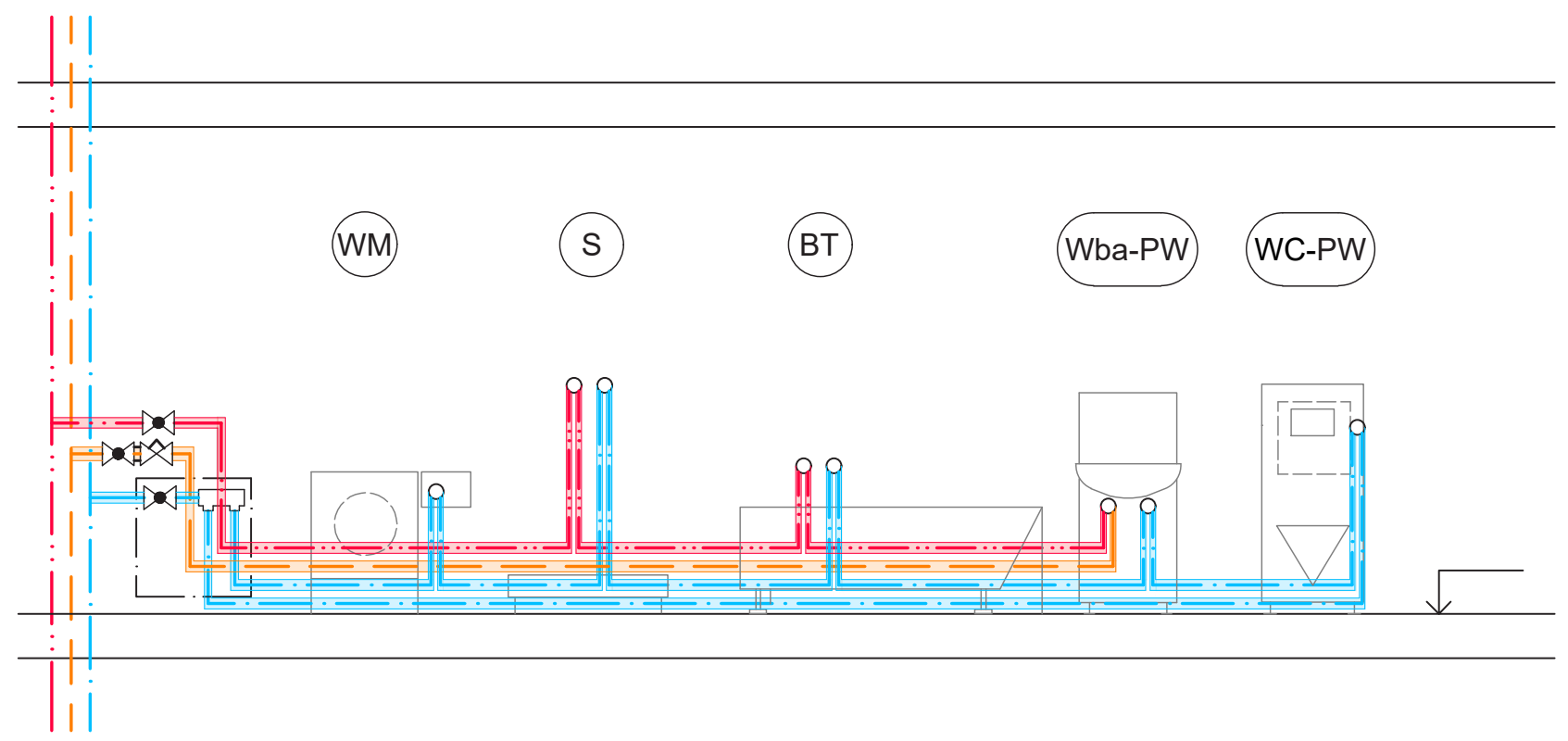

Fig. 7 Branch pipe connection with a ring mains with a hot water circulation [author]

\section{Automatic hygiene flushing unit}

If the water in the pipeline system stagnates, this may lead to its microbiological contamination. Water in the distribution system should be replaced at least once a week [10-12]. If it is not possible to change the water volume in the pipeline system manually, once a week, opening every release valve, an automatic hygiene flushing unit can be used. The unit has a compact design and they flush the section of pipe based on the program set on the control unit. The sanitary flushing units should be installed behind the last sanitary appliance in the section of the pipe that will be flushed (Fig. 10), and must be connected to the drainage system [13].

\section{Conclusion}

The contribution describes five alternative solutions of branch pipes of water installation. Branch pipes play a significant role in ensuring potable water quality. For single-family houses and apartment buildings, a continuous or ring mains installation are recommended. For office buildings, it is advised to install ring mains installation. For long sections of branch pipe, the ring main installation with a hot water circulation is recommended. For less used sanitary appliances, it is advised to use a Venturi dynamic flow splitter. For that sanitary appliance, where the water exchange at least once per a week it is not ensured, the automatic flushing units are invented. 


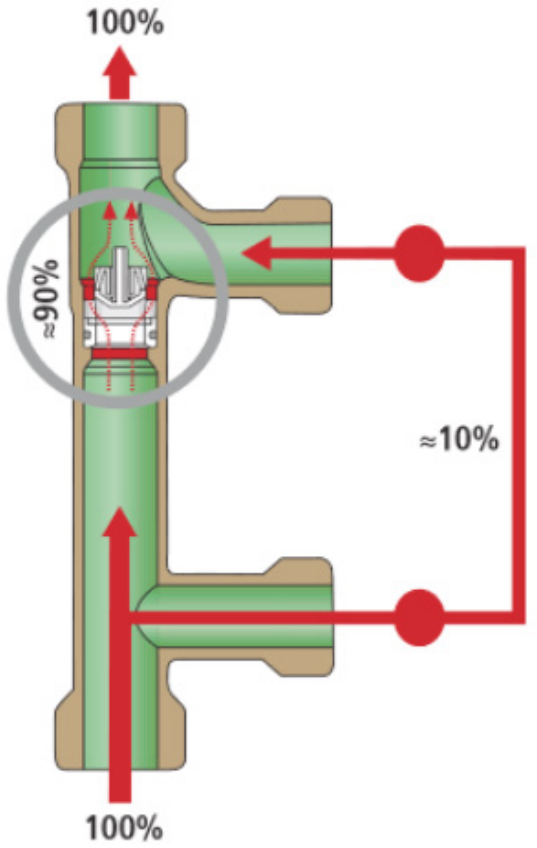

Fig. 8 Venturi dynamic flow splitter - the principle of function [9]

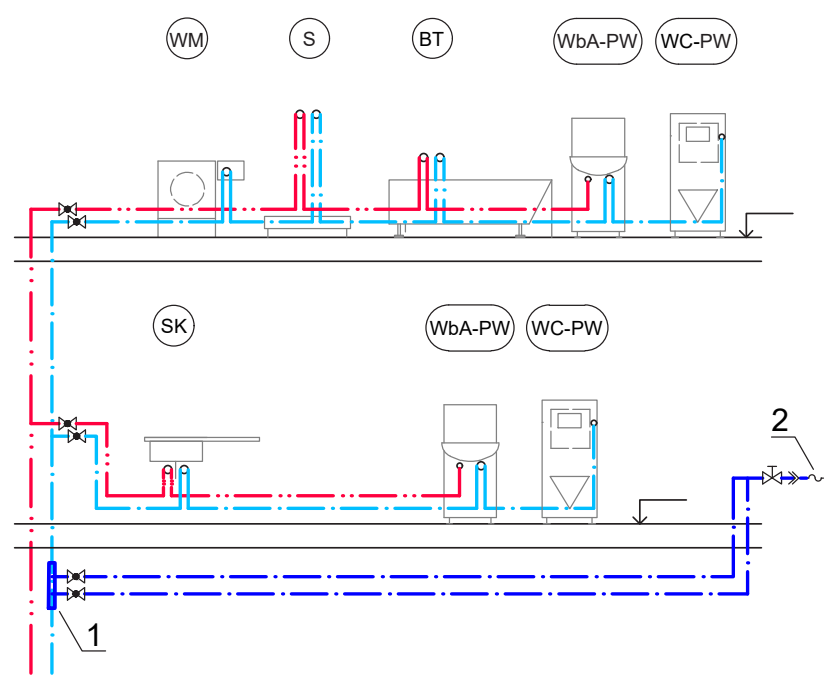

(1)

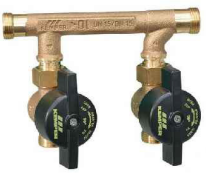

(2)

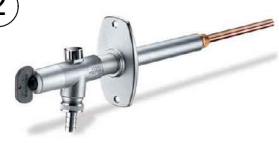

Fig. 9 Use of flow splitter in a single-family house in combination with a garden hose connection, 1: Venturi dynamic flow splitter [9], 2: frostproof outdoor fitting with hose connection [9]

The most commonly used alternative of installation of branch pipes in Slovakia is the T-pieces installation, because it is the cheapest alternative. In the paper are described more hygienically safe solutions.

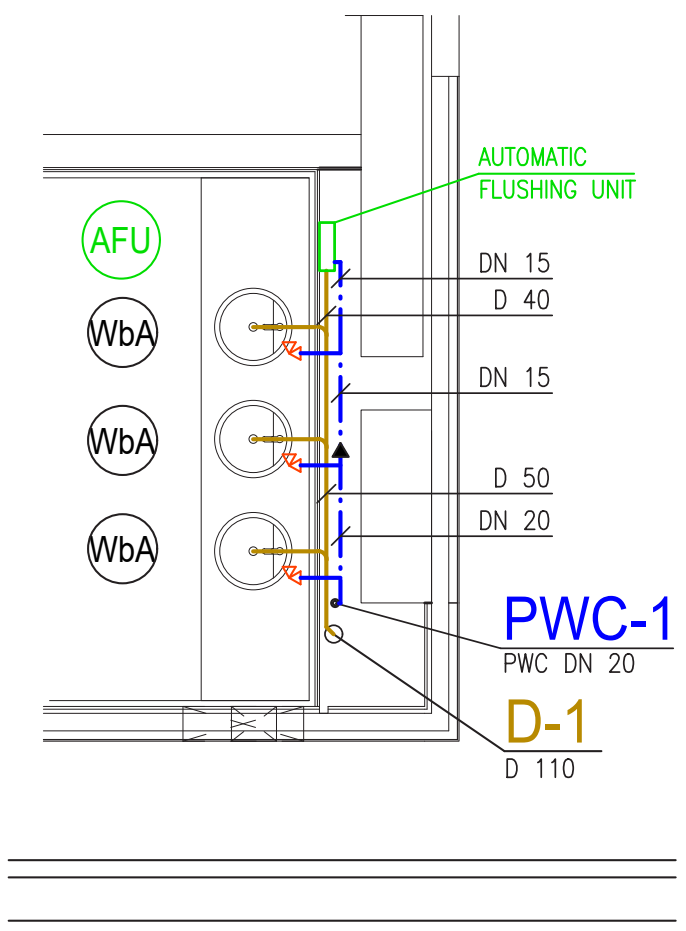

PWC-1

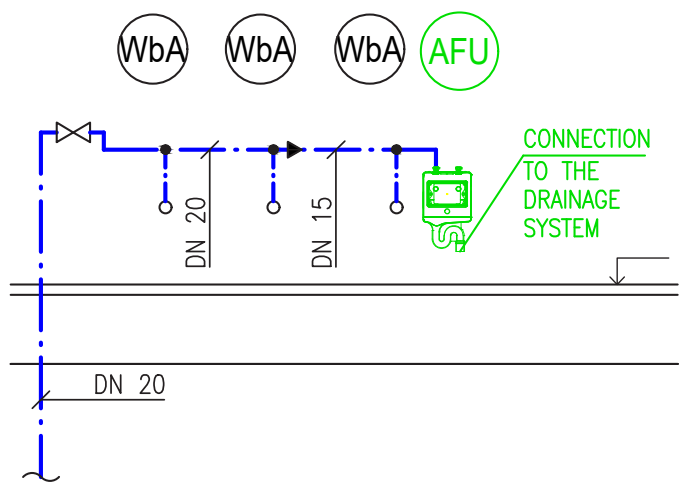

Fig. 10 Automatic hygiene flushing unit installed in a pre-wall system in order to flush a branch pipe [author], AFU: Automatic Flushing Unit [13], WbA: Wash basin, PWC: riser pipe of Potable Water Cold, D: Drainage

The question for the future is whether investors will want to switch from installing cheaper variants and using cheaper pipe materials to hygienically better water supply systems in the building.

\section{Acknowledgement}

This work was supported by Slovak Research and Development Agency and the Ministry of Education, Science, Research and Sport of the Slovak Republic through the grant VEGA 1/0847/18 and KEGA 044STU-4/2018. 


\section{References}

[1] The Council of the European Union Council Directive 98/83/EC of 3 November 1998 on the quality of water intended for human consumption.

[2] Peráčková, J. "Pitná voda-potravina č.1. Ako si udržat' jej kvalitu v budove?" (Potable water-food no.1. How to maintain its quality in the building?), TZB Haustechnik, 27(3), pp. 50-53, 2019. (in Slovak)

[3] van der Schee, W. G. "Regulation on Legionella prevention in collective water systems", In: The 31st International Symposium of CIB W062, Brussels, Belgium, 2005, pp. 1-16. [online] Available at: http://www.irbnet.de/daten/iconda/CIB12130.pdf [Accessed: 01 May 2020]

[4] La Mura, S., Jappolo, C. M., Pitera, L. A., Angermann, J. P., Izard, M. "Legionellosis Prevention in Building Water and HVAC Systems", REHVA, Brussels, Belgium, 2013.

[5] Schauer, C., Dinne, K., van der Schee, W., Mampaey, J., Gatto, I., Perackova, J., Petras, D., Bleys, B. "Hygiene in Potable Water Installations in Buildings - Requirements for design, deployment, operation and maintenance", REHVA, Brussels, Belgium, 2019.

[6] Forum Wasserhygiene "Planung, Errichtung, Inbetriebnahme und Betrieb von Trinkwasser-Installationen in Gebäuden Praxistaugliche Hinweisemit besonderem Fokus auf die hygienischen Aspekte" (Planning, construction, commissioning and operation of potable water installations in buildings - practical information with a special focus on hygienic aspect), Forum Wasserhygienie, Wien, Austria, 2018. (in German)

[7] Company UPONOR "Hygienic drinking water supply", [online] Available at: www.uponor.com/int/products/drinking-water-delivery [Accessed: 01 May 2020]
[8] Company REHAU "Technical information: Rautitan plumbing system, drinking water system", [online] Available at: www.rehau. com/downloads/378704/rautitan-plumbing-system-technical.pdf [Accessed: 01 May 2020]

[9] Company Kemper GmbH + Co. KG "KHS Flow-Splitter unit dynamic", [online] Available at: www.kemper-olpe.de/oc/business-units/building-technology/product-catalogue/hygiene-system-khs/khs-flow-splitter [Accessed: 01 May 2020]

[10] Eördöghné, M., Takács, J. "Analýza výskytu legionel v sústavách teplej vody a opatrenia proti nim prostriedkami projektovania" (Analysis of the occurrence of bacteria Legionella in hot water systems and measures against them by means of project design), In: SANHYGA 2017, Piešt’any, Slovakia, 2017, pp. 53-56. (in Slovak)

[11] Sinčak, P., Ondo, J., Kaposztasova, D., Virčikova, M., Vranayova, Z., Sabol, J. "Artificial Intelligence in Public Health Prevention of Legionelosis in Drinking Water Systems", International Journal of Environmental Research and Public Health, 11(8), pp. 8597-8611, 2014.

https://doi.org/10.3390/ijerph110808597

[12] Eördöghné, M. "Vplyv usporiadania potrubných rozvodov vodovodov na kvalitu pitnej vody a na jej zmenu" (The influence of the arrangement of water pipelines on the quality of drinking water and its change) In: Sanhyga 2015, Pieštany, Slovakia, 2015, pp. 63-69. (in Slovak)

[13] Company GEBERIT "Drinking water hygiene", [online] Available at: www.international.geberit.com/know-how/drinking-water-hygiene [Accessed: 01 May 2020] 